\title{
Development of laryngeal and pharyngeal function during long-term treadmill exercise in warmblood sport horses
}

\author{
Ann Kristin Barton ${ }^{1,2^{*}}$, Henning B. Löbert ${ }^{*}$ and Bernhard Ohnesorge ${ }^{l}$ \\ 1 Clinic for Horses, University of Veterinary Medicine Hanover, Foundation, Bünteweg 9, 30559 Hanover, Germany \\ 2 Equine Clinic, Free University of Berlin, Oertzenweg 19, 10169 Berlin, Germany \\ contributed equally to the study
}

\begin{abstract}
Summary
The influence of long-term treadmill exercise on upper airway function was to be evaluated in 16 warmbloods. Two high-speed treadmill endoscopies (HSTE) were performed after a warm-up period and after 25 minutes of exercise. 9 out of 16 horses presented with a respiratory noise, 6 showed signs of RLN (recurrent laryngeal neuropathy) grade $\geq$ Illa at rest. 5 of these 6 (83\%) developed a dynamic laryngeal collapse during HSTE. None of the 7 horses without a respiratory noise developed a dynamic collapse during exercise. Upper airway pathologies tended to deteriorate over time. All 5 cases of dynamic laryngeal collapse had been unable to fully abduct during endoscopy at rest without sedation. 3 of them (60\%) showed further deterioration during HSTE $(p=0.017)$. A partial pharyngeal collapse was found in 10 horses, but only 5 of them (50\%) presented with an abnormal respiratory noise. Overall, only 6 out of 9 horses (67\%) with abnormal respiratory noises were diagnosed with an upper airway obstruction of larynx and pharynx. The results show that pathologies of the upper airways may deteriorate during exercise. Therefore, endoscopic examinations during exercise should be continued beyond the first appearance of a respiratory noise to evaluate the full extent of upper airway pathologies.
\end{abstract}

Keywords: horse, exercise, RLN, high-speed treadmill, endoscopy

Correspondence: Ann Kristin Barton, DVM, Dipl. ECEIM, Equine Clinic, Veterinary Department, Free University of Berlin, Oertzenweg 19, 14163 Berlin, Germany, Email: ann-kristin.barton@fu-berlin.de

Citation: Barton A. C., Löbert H. B., Ohnesorge B. (2014) Development of laryngeal and pharyngeal function during long-term treadmill exercise in warmblood sport horses. Pferdeheilkunde 30, 68-80x

\section{Introduction}

Diagnosis of upper airway disease in the horse is routinely based on the evaluation of a respiratory noise during ridden exercise or longing in combination with endoscopic examinations at rest with or without sedation. In cases of dynamic upper airway stenosis, however, endoscopy at rest tends to be unrewarding. Dynamic endoscopy is described as the current gold standard for the diagnosis of dynamic upper airway disease (Franklin et al. 2008). The endoscopic evaluation during exercise can be performed on a high-speed treadmill or using overground scopes, a technique becoming more and more available in the field. Unfortunately, little data exists for warmbloods used as performance horses.

Recurrent laryngeal neuropathy (RLN) leading to a dynamic laryngeal collapse during exercise is the only exception, where international consensus exists that endoscopic examination at rest may be able to predict what happens during exercise in a majority of cases. In several studies (Parente et al. 1995, Hammer et al. 1998, Martin et al. 2000, Tan et al. 2005, Lane et al. 2006b, Franklin et al. 2006) $82-100 \%$ of horses, which could not reach full abduction of the left arytenoid cartilage at rest, showed a dynamic laryngeal collapse during exercise, whereas other authors (Rakestraw et al. 1991) did not find a dynamic collapse in the majority of horses. Intensity and duration of exercise may lead to this discrepancy of results (Hammer et al. 1998); therefore, development of upper airway stenosis in warmbloods during high-speed treadmill exercise was chosen as the subject of this study.

\section{Materials and Methods}

16 patients and clinic-owned horses were examined at the Clinic for Horses at the University of Veterinary Medicine Hanover, Foundation, Germany. They were warmbloods of mixed age (3-18 years), weight $(535-695 \mathrm{~kg})$, height (164-187cm) and gender (2 mares, 2 stallions, 12 geldings) with a history of an inspiratory respiratory noise and/or poor performance. Age less than 2 years or more than 20 years as well as cardiovascular, lower airway or orthopaedic disease led to exclusion from the study. Horses showing upper airway disease other than RLN and intermittent dorsal displacement of the soft palate during endoscopy at rest were also excluded from the study.

The horses were exercised on the longe line, 5 minutes with side-reins and 5 minutes without side-reins at the trot and 2.5 minutes with side-reins in canter. The occurrence of coughing and abnormal respiratory noises was documented and horses were categorized as shown in table 1. A typical "roaring" respiratory noise was characterized as an inspiratory sound of high, low or mixed frequency. Continuous respiratory noises 
were apparent on both reins in canter with and without sidereins. Horses without a respiratory noise were categorized as controls.

For the endoscopic examination, a flexible endoscope of $130 \mathrm{~cm}$ length and a diameter of $9.8 \mathrm{~mm}$ (Olympus PCF type 1301; Olympus Corporation, Tokyo, Japan) with a xenon light source and a digital processor (Olympus Exera CLV-160, Olympus Corporation, Tokyo, Japan) were used. The horses were examined without and with sedation via the right ventral nasal passage. Laryngeal motility at rest, after nasal occlusion for 30 seconds and after induction of swallowing by tipping the epiglottis with the endoscopic catheter was recorded on videos. After examination without sedation, the horses were sedated using detomidine hydrochloride (Domosedan; Pfizer $\mathrm{GmbH}$, Karlsruhe, Germany) $12-15 \mathrm{~g} / \mathrm{kg}$ IV and re-examined 3-5 minutes later.

Using the video processing program MPEG-Wizzard (WombleMultimedia Inc., USA) a short video sequence of 2-3 minutes length containing at least one minute of breathing at rest, one swallowing and nasal occlusion was anonymised and graded by three independant examiners. Laryngeal function was graded as described by Dixon (2003, table 2).

Endoscopic examination on the high-speed treadmill was carried out using the model "Kagra Mustang 2200" (Graber AG; Fahrwangen, Switzerland) after the horses had been trained on the treadmill $2-5$ times before endoscopy. The warmup protocol using a $3 \%$ slope consisted of 5 minutes walk at a speed of $1.8 \mathrm{~m} / \mathrm{s}, 2$ minutes trot at $3.6 \mathrm{~m} / \mathrm{s}$ and 1 minute gallop at $7.6 \mathrm{~m} / \mathrm{s}$, followed by a short stop to position and fixate the endoscope in the right ventral nasal passage. After placement of the endoscope, the horses were exercised for 3 minutes at $7.6 \mathrm{~m} / \mathrm{s}$. Then, the endoscope was removed and the horses were further exercised for 5 minutes at $3.6 \mathrm{~m} / \mathrm{s}$ (trot), 2 minutes at $7.6 \mathrm{~m} / \mathrm{s}$ (gallop), 5 minutes at $3.6 \mathrm{~m} / \mathrm{s}$ (trot), 2 minutes at $7.6 \mathrm{~m} / \mathrm{s}$ (galopp) and 5 minutes at $3.6 \mathrm{~m} / \mathrm{s}$ (trot). The treadmill was stopped again to place the endoscope in the right ventral nasal passage and another sequence of 3 minutes at $7.6 \mathrm{~m} / \mathrm{s}$ (galopp) followed. The endoscopic image of the larynx and pharynx was videotaped after the warm-up period and at the end of the exercise protocol; the equipment was removed from the nasal passage in between recordings to avoid damage of the upper airway mucosa. Examination on the treadmill was performed using a flexible endoscope of $160 \mathrm{~cm}$ length and a diameter of $9.8 \mathrm{~mm}$ (ETM Videotuning; Dr. Fritz GmbH, Tuttlingen, Germany) in combination with a xenon light source and a digital processor (ETM Eurolight Xenon-Praxis/ETM Eurocam pro; Dr. Fritz $\mathrm{GmbH}$, Tuttlingen, Germany). The videotapes were digitalised and processed using MPEG-Wizzard (Womble Multimedia Inc., USA). Afterwards, they were scored by three examiners at original speed and in slow motion at $50 \%$ of original speed. Pathological findings that may lead to dynamic collapse of pharynx and larynx as well as changes over time were described comparing two sequences of 2 minutes length at the beginning and the end of exercise.

Due to the small number of horses, the Fischer-Yates-Test was used to test the conditional probability for deterioration of pathologic findings during long-term exercise.

\begin{tabular}{lll}
\hline Table 1 & Categories of abnormal respiratory sounds \\
\hline Category & Character of respiratory sound \\
\hline A & No abnormal respiratory sound & \\
\cline { 2 - 3 } B & Typical discontinuous respiratory sound & Typical: inspiratory respiratory sound of high frequency, \\
C & Typical continuous respiratory sound & "roaring" typical for RLN \\
D & Typical respiratory noise and other untypical respiratory sound & \\
E & No typical respiratory sound, but other untypical respiratory sound & \\
\hline
\end{tabular}

\begin{tabular}{|c|c|c|}
\hline Table 2 & Scoring system for RLN by Ducharme (2005) & \\
\hline Grade & Description & Subgrade \\
\hline I & $\begin{array}{l}\text { All arytenoid movements synchronous and } \\
\text { symmetrical, full arytenoid abduction can be } \\
\text { achieved and maintained }\end{array}$ & \\
\hline ॥ & $\begin{array}{l}\text { Arytenoid movements asynchronous and/or larynx } \\
\text { asymmetrical at times but full arytenoid abduction } \\
\text { can be achieved and maintained }\end{array}$ & $\begin{array}{l}\text { a. Transient asynchrony, flutter or delayed movements } \\
\text { b. Asymmetry of the Rima glottidis much of the time due to reduced mobility of the } \\
\text { affected arytenoid and vocal fold, but occasions, typically after swallowing or } \\
\text { nasal occlusion, when full symmetrical abduction is achieved and maintained }\end{array}$ \\
\hline III & $\begin{array}{l}\text { Arytenoid movements asynchronous and/or } \\
\text { asymmetric. Full arytenoid abduction cannot be } \\
\text { achieved and maintained }\end{array}$ & $\begin{array}{l}\text { a. Asymmetry of the Rima glottidis much of the time due to reduced mobility of the } \\
\text { arytenoid cartilage and vocal fold, but occasions, typically after swallowing of } \\
\text { nasal occlusion, when full symmetrical abduction is achieved but not } \\
\text { maintained } \\
\text { b. Obvious arytenoid abductor muscle deficit and arytenoid cartilage asymmetry. } \\
\text { Full abduction is never achieved. } \\
\text { c. Marked but not total arytenoid abductor muscle deficit and arytenoid cartilage } \\
\text { asymmetry with little arytenoid cartilage movement. Full abduction is never } \\
\text { achieved. }\end{array}$ \\
\hline IV & Complete immobility of the arytenoid and vocal fold & \\
\hline
\end{tabular}




\section{Results}

\section{a) Endoscopy at rest}

The results of the endoscopic examination regarding RLN at rest according to the 4-point-grading system summarized by Dixon (2003, table 2) are shown in table $3 a$ (horses without respiratory noise) and $3 b$ (horses with respiratory noise) in comparison to the respiratory noise during longing exercise and findings of the endoscopy on the highspeed treadmill.

All horses without a respiratory noise were categorized as controls and showed RLN findings less than grade III during endoscopic examination at rest before sedation; one of them was classified as grade IIlb after sedation and one remained a case of doubt (No.9, table 3a). 11 of 16 horses were categorized as a higher grade of RLN after sedation; 5 horses were categorized as the same grade before and after sedation (table $3 a$ and $3 b$ ). All 3 horses with completely symmetric and synchronous laryngeal movements before sedation showed temporary or continuous asymmetric and/or asynchronous movements of the arytenoids after sedation, but maintained the ability for complete abduction.

\section{b) Results of dynamic endoscopy}

The results of the HSTE of the 7 horses without a respiratory noise (control group) are shown in table $3 a$; the results of the

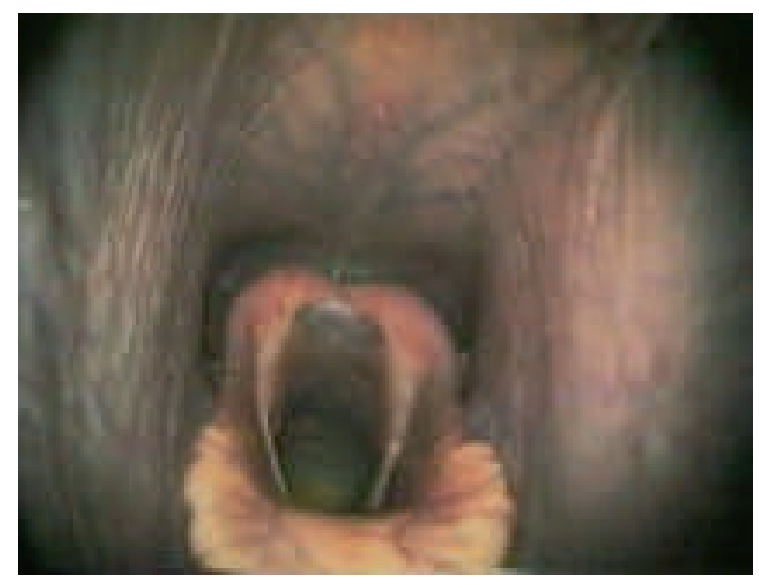

Fig. 1a Maximal abduction deficit during inspiration at the beginning of exercise in horse No. 14
9 horses with a respiratory noise are shown in table $3 b$. In 5 horses presenting with a respiratory noise, a partial dynamic collapse of the arytenoid cartilages was visible during HSTE; the left arytenoid was affected in 4 horses and the right arytenoid in one horse. Although this collapse was visible at the beginning of exercise in all 5 horses, 3 horses $(67 \%)$ showed deterioration in the ability to abduct the affected arytenoid at the second examination; a complete collapse did not occur in any of the cases. The deterioration in maximum abduction of the left arytenoid at the end of exercise compared to the beginning in horse No. 14 is shown in figures $1 \mathrm{a}$ and $1 \mathrm{~b}$. All 5 horses had not been able to reach or uphold complete abduction at rest (table 3b). None of the horses without a respiratory noise (control group, table $3 a$ ) showed an arytenoid collapse during exercise.

A dynamic vocal cord collapse was visible in 3 horses. One horse showed a collapse of both vocal cords combined with a left-sided partial arytenoid collapse at the beginning and at the end of exercise, while the other two horses deteriorated during exercise and only showed pathological findings at the end of exercise.

9 out of 16 horses had an expiratory abduction deficit (EAD, reduced abduction during expiration) at the beginning of exercise and 7 of them (78\%) deteriorated further during exercise. In 7 horses, both arytenoids remained at full abduction during inspiration and expiration for the entire duration of the exercise period.

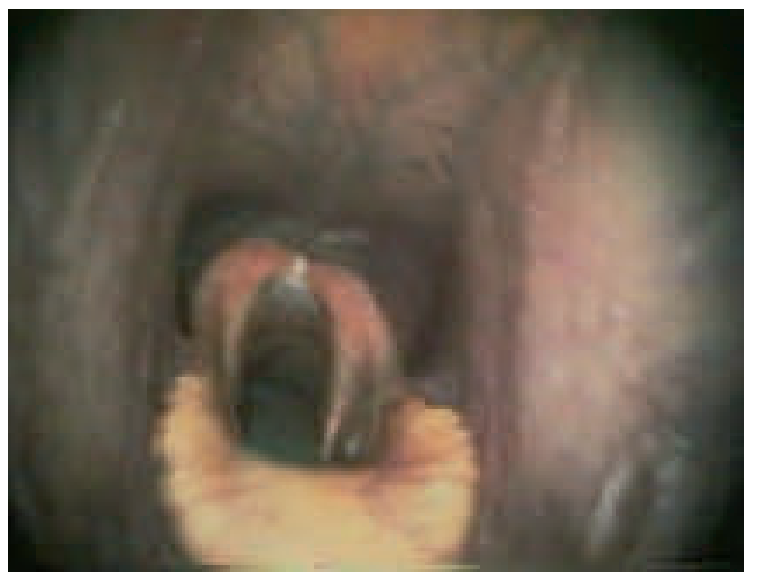

Fig. 1b Deterioration of left arytenoid abduction deficit at the end of exercise in horse No. 14

\begin{tabular}{|c|c|c|c|c|c|c|c|c|c|c|c|c|c|}
\hline \multirow{3}{*}{ No } & \multirow{3}{*}{$\begin{array}{l}\text { Resp. } \\
\text { Noise }\end{array}$} & \multirow{2}{*}{\multicolumn{2}{|c|}{$\begin{array}{c}\begin{array}{c}\text { Pathological } \\
\text { findings at rest }\end{array} \\
\text { RLN }\end{array}$}} & \multicolumn{10}{|c|}{$\begin{array}{l}\text { Dynamic pathological findings } \\
\left(0^{\prime}: \text { beginning, } 25^{\prime} \text { : end of exercise }\right)\end{array}$} \\
\hline & & & & \multicolumn{2}{|c|}{$A C C$} & \multicolumn{2}{|c|}{ VCC } & \multicolumn{2}{|c|}{ ADAF } & \multicolumn{2}{|c|}{ PRC } & \multicolumn{2}{|c|}{ PWC } \\
\hline & & b.s. & a.s. & $0^{\prime}$ & $25^{\prime}$ & $0^{\prime}$ & $25^{\prime}$ & $0^{\prime}$ & $25^{\prime}$ & $0^{\prime}$ & $25^{\prime}$ & $0^{\prime}$ & $25^{\prime}$ \\
\hline 1 & A & I & Ila & & & & & & $r++$ & & & & \\
\hline 5 & A & $\| l a$ & Ila & & & & & & & & & + & + \\
\hline 6 & A & Ila & Ilb & & & & & & & ++ & ++ & & \\
\hline 7 & A & $\mathrm{Ilb}$ & $11 \mathrm{~b}$ & & & & & & & + & + & & \\
\hline 8 & A & $\mathrm{Ilb}$ & $1 \mathrm{lb}$ & & & & & & & & & & \\
\hline 9 & A & Ilb & $\mathrm{Ilb} / \mathrm{Illa}$ & & & & & & & ++ & ++ & & \\
\hline 11 & A & $\mathrm{Ilb}$ & IIIb & & & & & & & + & ++ & & \\
\hline
\end{tabular}


In 3 horses, an axial deviation of the aryepiglottic fold (ADAF) was visible during dynamic endoscopy, which became obvious at the first examination in 2 horses; the third horse deteriorated during exercise so that the deviation was found at the end of exercise. In all 3 horses, the right aryepiglottic fold was affected although 2 horses showed left-sided RLN during endoscopy at rest. One of them (No 15) had a combination of arytenoid and vocal cord collapse of both sides in addition to the axial deviation of the right aryepiglottic fold (table 3b).

A partial pharyngeal roof collapse (PRC) was found in 9 horses. In 5 horses, the dorsal pharyngeal wall lowered to the level of the proximal arytenoid border, in 4 horses the collapse was more severe. 2 horses (22\%) deteriorated during exercise, but none showed a complete collapse at any time during dynamic endoscopy. In 7 horses, the pharyngeal roof was stable above the level of the proximal arytenoid border at all times.

Only 2 horses showed a very moderate pharyngeal wall collapse (PWC), which did not exceed the lateral border of the epiglottis. Findings did not change between the beginning and end of exercise.

Using the Fisher-Yates-test, a significant deterioration of pathological findings was detected for horses with RLN (arytenoid cartilage collapse) between the beginning and the end of exercise $(p=0.017)$, while this did not prove to be true for the other pathologies like PRC. A scoring-system for EAD has not been established; therefore the significance of deterioration could not be calculated.

\section{c) Respiratory noises}

9 of the examined horsed had a respiratory noise during longing exercise (table $3 \mathrm{~b}$ ), which was a continuous or discontinuous inspiratory sound of high frequency, typical for RLN. In 2 (No. 2 and 14) of these 9 horses, an additional atypical sound was noted. In 5 (No. 4, 13-16) out of the 9 (56\%), a partial arytenoid collapse was found during dynamic endoscopy; in one horse (No. 10) without ACC and VCC, an axial deviation of the right aryepiglottic fold was suspected to be the cause of the synchronous respiratory noise. In 3 horses with a typical "roaring" noise (No. 2, 3, 12), the only findings during dynamic endoscopy were a slight collapse of the dorsal or lateral pharyngeal walls with no obvious findings in the larynx.

One (No. 1) out of 7 horses without a respiratory noise (table $3 a$ ) showed a deviation of the aryepiglottic fold; in one (No. 8) the caudal aspect of the soft palate was unstable during dynamic endosopy with following DDSP (dorsal displacement of the soft palate), and the other 5 horses (No. 5-7, $9,11)$ presented with a slight collapse of the dorsal or lateral pharyngeal walls with no findings on the larynx.

\section{Discussion}

The aim of the present study was to examine the effects of long-term treadmill exercise on findings in the equine upper airways in comparison to endoscopic findings at rest before and after sedation in horses with and without a respiratory noise during exercise. Therefore, the laryngeal motility was scored using anonymised videos by three independant examiners before and after the horses had been sedated, which is comparable to earlier studies (Ricketts et al. 1986, Ohnesorge et al. 1991, Lindegaard et al. 2007, Barton et al. 2011). The ability to completely abduct the left arytenoid was scored after swallowing, as this leads to the highest grade of abduction in horses affected by RLN (Barton et al. $2011)$. After sedation, the abduction deficit increased in the majority of horses during endoscopy at rest. Archer et al. (1991) also found a decreased ability to abduct the left arytenoid after the application of xylazine. Detomidine also caused asymmetric laryngeal movements (Lindegaard et al. 2007), which had not been visible before sedation. These results correspond with the presented data in which 3 horses only showed arytenoid asymmetry after sedation, and the results of other authors (Ducharme et al. 1991) who also

\begin{tabular}{|c|c|c|c|c|c|c|c|c|c|c|c|c|c|}
\hline Table & & \multirow{3}{*}{\multicolumn{2}{|c|}{$\begin{array}{c}\text { Pathological } \\
\text { findings at rest }\end{array}$}} & \multicolumn{10}{|c|}{ Results of endoscopic examinations at rest and on the HSTM of horses with a respiratory noise } \\
\hline \multirow{3}{*}{ No } & \multirow{3}{*}{$\begin{array}{l}\text { Resp. } \\
\text { Noise }\end{array}$} & & & \multicolumn{10}{|c|}{$\begin{array}{c}\text { Dynamic pathological findings } \\
\left(0^{\prime}: \text { beginning, } 25^{\prime}: \text { end of exercise) }\right.\end{array}$} \\
\hline & & & & & & & & & & & & & \\
\hline & & BS & AS & $0^{\prime}$ & $25^{\prime}$ & $0^{\prime}$ & $25^{\prime}$ & $0^{\prime}$ & $25^{\prime}$ & $0^{\prime}$ & $25^{\prime}$ & $0^{\prime}$ & $25^{\prime}$ \\
\hline 2 & $\mathrm{D}$ & I & Ila & & & & & & & + & + & & \\
\hline 3 & $B$ & 1 & $\mathrm{Ilb}$ & & & & & & & & & & \\
\hline 4 & $C$ & IIIb $(r)$ & $\mathrm{Ilb}(\mathrm{r})$ & $r+$ & $r+$ & & & & & & & & \\
\hline 10 & $C$ & $1 \mathrm{llb}$ & $\mathrm{Ilb} / \mathrm{llla}$ & & & & & $r+$ & $r++$ & ++ & ++ & + & + \\
\hline 12 & $C$ & $\mathrm{Ilb} / \mathrm{Illa}$ & IIla/b & & & & & & & + & ++ & & \\
\hline 13 & $B$ & $\mathrm{Ilb} / \mathrm{llla}$ & IIla/b & $1+$ & $1+$ & & & & & + & + & & \\
\hline 14 & $D$ & Illa & IIlb & $1+$ & $1++$ & & $1+$ & & & & & & \\
\hline 15 & $C$ & IIlb & IIlb & $1+$ & $1++$ & $\mathrm{I} / \mathrm{r}$ & $1 / r$ & $r+$ & $r++$ & & & & \\
\hline 16 & $C$ & Illb & IIlb & $1+$ & $1++$ & & $1+$ & & & ++ & ++ & & \\
\hline
\end{tabular}

$\mathrm{I}=$ left, $\mathrm{r}=$ right, $\mathrm{RLN}=$ recurrent laryngeal neuropathy, $\mathrm{ACC}=$ arytenoid cartilage collapse, $\mathrm{VCC}=$ vocal cord collapse, $\mathrm{ADAF}=$ axial deviation of aryepiglottic fold, $\mathrm{PRC}=$ pharyngeal roof collapse, $\mathrm{PWC}=$ pharyngeal wall collapse, b.s. $=$ before sedation, a.s. $=$ after sedation, $+=$ moderate finding / deterioration, $++=$ severe finding / deterioration 
found $10 \%$ of sedated horses to lose their ability to fully abduct the left arytenoid after swallowing. This increased abduction deficit after sedation is surely not a pharmacological action of the sedative. Early studies (Cook 1981) come to the conclusion that a systemically applied substance as detomidine, which acts on synapses of the CNS, cannot have a unilateral effect on the left recurrent laryngeal nerve and the intrinsic laryngeal musculature. Furthermore, only some horses show this unilateral abduction deficit after sedation, regardless of the dosage. Therefore, the increased abduction deficit in these horses cannot be explained as a side effect of the pharmacological compound or an artefact. It is more likely that it is an indicator of early neurogenic muscle atrophy. Several authors showed in their studies that histopathological findings of muscle atrophy are often more advanced than the visible abduction deficit allows suspecting (Deegen et al. 2000, Duncan et al. 1974 and 1977). In conclusion, the examination of horses after sedation may help to identify subclinical cases of RLN that develop asymmetric laryngeal motility or show an increase in abduction deficit after sedation. To allow a more precise interpretation of these findings in the sedated horse, a larger number of horses should be examined by dynamic endoscopy. None of the 3 horses in this study that developed laryngeal asymmetry after sedation showed a dynamic laryngeal collapse on the treadmill. As these horses were able to fully abduct their arytenoids during exercise, they seem to be free of clinical disease, although they might have histopathological changes of neurogenic muscle atrophy which may lead to laryngeal dysfunction in the future.

It was impossible in 6 horses, 2 before sedation and in 4 after sedation, to grade them according to Dixon (2003), as their findings varied during the examination (table $3 a$ and $3 \mathrm{~b})$. If it is difficult to distinguish between grade IIb and IIla, which is considered the border to clinical relevance of RLN, the case is hard to handle. If it remains unclear in horses presenting with a respiratory noise after endoscopy at rest whether these horses are affected by clinical RLN or not, conflicts with breeding survey regulations for German warmbloods and sale of goods law may follow. Even those horses that can be clearly graded according to their ability to abduct after swallowing may be problematic, as several studies (Morris et al. 1990, Rakestraw et al. 1991, Parente 1995, Hammer et al. 1998, Martin et al. 2000, Tan et al. 2005, Lane et al. 2006b) have shown that even horses incapable of full abduction after nasal occlusion or swallowing may show a physiological function of the larynx during highspeed treadmill endoscopy. Also, a small proportion of horses without signs of laryngeal dysfunction during endoscopy at rest may develop a dynamic collapse during exercise. Therefore, the decision for or against the diagnosis of clinical disease of RLN in the individual horse should be taken with caution and endoscopy during exercise should be considered in critical cases, especially in those which are inconclusive during endoscopy at rest.

Dynamic endoscopy was performed on a high-speed treadmill at the beginning and at the end of an exercise programme containing alternating phases of trot and gallop, which is typical for the daily work of a sports horse. The speed of the treadmill for the trot periods was chosen to be $3.6 \mathrm{~m} / \mathrm{s}$ in accordance to a working trot in a warmblood. The speed for gallop was chosen to be $7.6 \mathrm{~m} / \mathrm{s}$, which exceeds the speed of canter at $5-5.5 \mathrm{~m} / \mathrm{s}$, to compensate for the missing weight of the rider and flexion of the head in dressage. In show jumping and eventing, speeds exceeding normal canter are also required. It was not possible to use or compare our exercise protocol with those of former studies on the high-speed treadmill (Morris and Seehermann 1990, Rakestraw et al. 1991, Parente 1995, Hammer et al. 1998, Martin et al. 2000, Tan et al. 2005, Lane et al. 2006a), as all those studies were performed on standard- and thoroughbreds. To our knowledge, this is the first HSTE study performed in warmbloods, which exercise under very different conditions and often at an older age compared to standard-and thoroughbreds.

A dynamic laryngeal collapse can occur as an isolated collapse of the arytenoids, an isolated collapse of the vocal cords or as a combination of both (Tan et al. 2005, Lane et al. 2006a). The left arytenoid collapse is most likely a consequence of RLN (Lane et al. 2006a). Several studies have shown that $82-100 \%$ of unsedated horses which do not reach full abduction of the left arytenoid during endoscopy at rest or are unable to maintain maximum abduction develop a dynamic collapse during exercise (Parente 1995, Hammer et al. 1998, Martin et al. 2000, Tan et al. 2005, Lane et al. 2006b, Franklin et al. 2006). On the other hand, only 0$26 \%$ of horses without an abduction deficit during endoscopy at rest showed a dynamic collapse on the high-speed treadmill. In this study, 4 horses (No. 4, 14-16) had a permanent abduction deficit before sedation at rest (grade $\mathrm{Ill} / \mathrm{lll} / \mathrm{b}$ ) and one (No. 13) could reach full abduction before but not after sedation. All 5 of these horses developed a partial arytenoid collapse during exercise. None of the horses that reached and maintained full abduction at rest before sedation had a dynamic collapse during exercise, so our results in warmbloods agree with former studies in standard-and thoroughbreds. One needs to keep in mind, however, that up to $18 \%$ of horses with an abduction deficit at rest reach full abduction during exercise and that up to $26 \%$ of horses without pathological findings during endoscopy at rest show laryngeal collapse during dynamic endoscopy. Therefore, dynamic endoscopy should be recommended in any case in which a definite classification of clinical disease is required.

In 3 out of 5 horses (No. 14-16) showing a partial arytenoid collapse in this study, the abduction deficit increased from the first to the second examination at the end of exercise. All were graded $\geq$ Illa during endoscopy at rest. The advanced pathological neurogenic atrophy of the intrinsic laryngeal musculature may lead to exhaustion of these muscles and a decreased ability of arytenoid abduction during long-term exercise. Another explanation may be an increase in negative pressure during inspiration under intense breathing, thus pulling the left arytenoid into the laryngeal lumen. The definition of clinical disease in RLN as a combination of a typical inspiratory respiratory noise and an abduction deficit $\geq$ grade IIla is supported by the results of this study, as all horses presenting with partial arytenoid collapse during HSTE fulfilled these criteria. In 2 of the 3 horses with a deterioration of arytenoid collapse during exercise, an ipsilateral vocal cord collapse occurred only at the second examination. This supports the general assumption that a vocal cord collapse tends to occur secondary to an arytenoid collapse (Parente 2004). On the other hand, one horse developed a right sided vocal cord collapse 
without an arytenoid collapse. An isolated vocal cord collapse has been reported by several authors (Morris und Sehermann 1990, Rakestraw et al. 1991, Kannegieter und Dore 1995, Kings et al. 2001, Franklin et al. 2006, Lane et al. $2006 \mathrm{~b}$ ). The aetiology is unknown; a subtle form of RLN is suspected (Kings et al. 2001). None of the horses with full arytenoid abduction at the first endoscopy developed an abduction deficit until the second examination. In horses No. $10-13$ the outcome of high-speed treadmill endoscopy was not predictable by the results of the endoscopic examination at rest. Sedation may lead to increased recognition of an abduction deficit that becomes relevant during HSTE (No. 13), or an abduction deficit under sedation may have no predictive value (No. 9, 10, 12). The respiratory noise in horse No. 10 and 12 was more likely caused by ADAF or pharyngeal collapse respectively, despite findings of RLN during endoscopy at rest, as no abduction deficit was visible during exercise.

9 out of 16 horses did not show full abduction of the arytenoids during expiration at the beginning of exercise and 7 of them deteriorated further during exercise. In contrast to an inspiratory abduction deficit, an expiratory abduction deficit has not been described before. As there was no correlation to findings of RLN at rest or a dynamic collapse, the pathological relevance seems unsure at this time. As most horses deteriorated during exercise, exhaustion of the abductors can be suspected as aetiology. Although this might indicate abductor muscles' weakness, it seems to be irrelevant in terms of clinical disease, as an expiratory abduction deficit does not compromise the physiological function of breathing.

The axial deviation of the aryepiglottic fold (ADAF), often combined with a history of a respiratory noise or exercise insufficiency, has been described with a prevalence of $5-55 \%$ in racing horses (Morris und Sehermann 1990, Rakestraw et al. 1991, Kannegieter und Dore 1995, Kings et al. 2001, Martin et al. 2000). ADAF might occur on the left or right side or as a combination of both and is often an isolated finding (Morris und Sehermann 1990, Rakestraw et al. 1991, Parente 1994, Kings et al. 2001, Martin et al. 2000), but may also occur in combination with dynamicstenotic pathologies of the upper airways (Morris und Sehermann 1990, Rakestraw et al. 1991). In the present study, right sided ADAF was found in 3 out of 16 warmbloods and deteriorated towards the end of exercise. The aetiology remains unclear; increased inspiratory negative pressure at the end of exercise is suspected to be a main factor. Parente (1994) suspected a correlation to palatal dysfunction. In this study, no correlation to other upper airway findings was apparent.

Palatal instability of the caudal aspect of the soft palate, characterized by progressive, wave-like dorso-ventral movements of the mucosa, has been described by several authors (Morris und Sehermann 1990, Rakestraw et al. 1991, Kings et al. 2001). It often precedes a dorsal displacement of the soft palate (DDSP). Therefore, both findings have been suspected to be two manifestations of the same disease (Morris und Sehermann 1990). We found the same in one horse of this study. The DDSP was spontaneously corrected after some breathing cycles, but soon palatal instability was obvious again, leading to recurrent DDSP.
Towards the end of exercise, DDSP did not occur any more. It has been suspected that palatal instability and subsequent DDSP are caused by laryngeal retraction in nervous horses (Cook 1981), so ongoing exercise and exhaustion of the larynx retracting muscles may lead to increased stability of the soft palate.

Dynamic collapse of the pharynx is a rare stenotic disease of the upper airways described in 1.3-4\% of racehorses examined by HSTE for exercise insufficiency or a respiratory noise (Morris und Sehermann 1990, Rakestraw et al. 1991, Kings et al. 2001). Martin et al. (2000) found a prevalence of $27 \%$, which might be explained by the high proportion of standardbreds in this study. Standardbreds race in a more flexed head position which might support the development of a dynamic pharyngeal collapse. Several authors (Franklin et al. 2006, Cehak et al. 2010, Davidson et al. 2002, Strand et al. 2009) report an increased prevalence in sport horses compared to racing horses. Strand et al. (2009) also found a correlation between head position and pharyngeal collapse in Norwegian trotters. In our study, a pharyngeal roof collapse was found in 8 horses, a pharyngeal wall collapse in one horse, and one horse showed a combination of both (table $3 a$ and $3 b)$. This dynamic collapse deteriorated in only 2 horses during exercise, and according to Boyle et al. (2006), all cases could be classified as mild. The aetiology of dynamic pharyngeal collapse is unknown; again, the increase of negative inspiratory pressure during strenuous exercise might be an important factor.

Respiratory noises occur in all dynamic-stenotic pathologies of equine upper airways. In this study, one out of 7 horses without a respiratory noise showed a moderate axial deviation of the aryepiglottic fold. Kings et al. (2001) found only $83 \%$ of horses with ADAF to have a respiratory noise appearing synchronously to the pathological vibration of the mucosal fold, $11 \%$ had a moderate ADAF without a respiratory noise. Therefore, an ADAF may not explain a respiratory noise in every case. The same seems to be true for the pharyngeal collapse, as this phenomenon occurred in 5 of 7 horses without a respiratory noise in our study, in Boyle's (2006) study only $73 \%$ of all horses with a pharyngeal collapse developed a respiratory noise. The results of the present study allow the assumption that in most cases, a mild pharyngeal collapse does not lead to a respiratory noise. This is supported by other studies; Franklin et al. (2006) found only mild inspiratory sounds in horses with pharyngeal instability, and DDSP occurs without a notable respiratory noise in up to $30 \%$ of cases (Martin et al. 2000, Parente 2002). An arytenoid collapse occurred in combination with an inspiratory sound of high frequency in all 5 horses of the present study. Several authors (Moris und Sehermann 1990, Franklin et al. 2006) also found an inspiratory noise in all horses with laryngeal collapse in their studies, although the sound was not necessarily of high frequency. 3 horses in our study presented with a respiratory noise, but showed no pathologies during endoscopy at rest and on the treadmill apart from a very mild pharyngeal collapse and a mild expiratory arytenoid collapse which was probably not the reason for the inspiratory respiratory noise. The respiratory noise might have been caused by turbulences of air flow in the nasal passages; in these cases, dynamic endoscopy does often not lead to a diagnosis. 
In conclusion, upper airway pathologies may change during long-term exercise and HSTE; this effect was found to be statistically significant for arytenoid collapse in this study. Pathological findings of the aryepiglottic folds, the soft palate and the pharynx deteriorated over time in a noticeable proportion of horses during dynamic endoscopy. No statistically significant effect of long-term exercise was found for these pathologies, but it may be found in larger study populations. The question whether arytenoid collapse was caused by an increase of inspiratory negative pressure under strenuous exercise or by exhaustion of the intrinsic abducting musculature, possibly indicating more severe histopathological changes of laryngeal muscles in these horses, needs to be studied on a higher number of individuals and needs to include histological examinations. As the exercise protocol was the same for all individuals, however, exhaustion of the atrophied dorsal cricoarytenoid muscle may be the more likely explanation.

In any case, dynamic endoscopy on the treadmill or the use of the new portable systems is a very valuable technique for the examination of equine upper airways and an adequate length and intensity of exercise might help to reproduce dynamic-stenotic pathologies during the examination. The present study also shows that only if the respiratory noise coincides with the endoscopically visible stenosis of the upper airway, a definite diagnosis can be established. Endoscopic examinations during exercise should be continued after first appearance of a respiratory noise to evaluate the full extent of upper airway pathologies.

\section{References}

Archer R. M., Lindsay W. A., Duncan I. D. (1991) A comparison of techniques to enhance the evaluation of equine laryngeal function. Equine Vet. J. 23, 104-107

Barton A., Löbert H., Ohnesorge B. (2011) Zum Einfluss der Sedierung in der ruheendoskopischen Untersuchung der linksseitigen Kehlkopflähmung beim Warmblutpferd. Pferdeheilkunde 27, 674680

Boyle A. G., Martin B. B., Davidson E. J., Durando M. M., Birks E. K. (2006) Dynamic pharyngeal collapse in racehorses. Equine Vet. J. (Suppl), 546-550

Cehak A., Rohn K., Barton A., Stadler P., Ohnesorge B. (2010) Effect of head and neck position on pharyngeal diameter in horses. Vet. Radiol. Ultrasound 51, 491-497

Cook W. R. (1981) Some observations on form and function of the equine upper airway in health and disease: 1. The Pharynx. Proc. Am. Assoc. Equine Pract. 27, 355

Dart A. J., Dowling B. A., Hodgson D. R., Rose R. J. (2001) Evaluation of high-speed treadmill videoendoscopy for diagnosis of upper respiratory tract dysfunction in horses. Aust. Vet. J. 79, 109-112

Davidson E. J., Martin B. B., Parente E. J., Birks E. K. (2002) Dynamic evaluation of sport horses with poor performance: 80 cases (1992-2000). In: Proceedings of the 2002 Conference on Equine Sports Medicine: The Elite Dressage and Three-Day-Event Horse, CESMAS 2002, Jülich, 133-136.

Deegen E., Brickwedel I., Ohnesorge B. (2000) Endoskopie- und Obduktionsbefunde des Kehlkopfes beim Pferd. Tierärztl. Praxis 28 (G), 140-147

Dixon P. M., Robinson N. E., Wade J. F. (2003) Workshop summary. In: Equine Recurrent Laryngeal Neuropathy. Stratford-upon-Avon 2003, 93-97

Ducharme N. G., Hackett R. P., Fubini S. L., Erb H. N. (1991) The reliability of endoscopic examination in assessment of arytenoid cartilage movement in horses. Part II. Influence of side of examination, re-examination, and sedation. Vet Surg 20, 180-184
Ducharme N. G. (2005) Upper Airway: Clinical Perspectives. In: Third World Equine Airways Symposium 2005, Berlin, Germany, $131-136$

Duncan I. D., Griffith I. R., McQueen A., Baker G. O. (1974) The pathology of equine laryngeal hemiplegia. Acta neuropathologica 27, 337-348

Duncan I. D., Baker G. J., Heffron C. J., Griffith I. R. (1977) A correlation of the endoscopic and pathological changes in subclinical pathology of the horse's larynx. Equine Vet. J. 9, 220-225

Franklin S. H., Naylor J. R., Lane J. G. (2006) Videoendoscopic evaluation of the upper respiratory tract in 93 sport horses during exercise testing on a high-speed treadmill. Equine Vet. J. (Suppl). 540-545

Hammer E. J., Tulleners E.P., Parente E. J., Martin B. B. Jr. (1998) Videoendoscopic assessment of dynamic laryngeal function during exercise in horses with grade-III left laryngeal hemiparesis at rest: 26 cases (1992-1995). J. Am. Vet. Med. Assoc. 212, 399-403

Kannegieter N. J., Dore M. L. (1995) Endoscopy of the upper respiratory tract during treadmill exercise: a clinical study of 100 horses. Aust. Vet. J. 72, 101-107

Kings D. S., Tulleners E., Martin B. B., Parente E. J., Boston R. (2001) Clinical experiences with axial deviation of the aryepiglottic folds in 52 racehorses. Vet. Surg. 30, 151-160

Lane J. G., Bladon B., Little D. R., Naylor J. R., Franklin S. H. (2006a) Dynamic obstructions of the equine upper respiratory tract. Part 1 : observations during high-speed treadmill endoscopy of 600 Thoroughbred racehorses. Equine Vet. J. 38, 393-399

Lane J. G., Bladon B., Little D. R., Naylor J. R., Franklin S. H. (2006b) Dynamic obstructions of the equine upper respiratory tract. Part 2: comparison of endoscopic findings at rest and during high-speed treadmill exercise of 600 Thoroughbred racehorses. Equine Vet. J. $38,401-407$

Lindegaard C., Husted L., Ullum H., Fieldborg J. (2007) Sedation with detomidine and acepromazine influences the endoscopic evaluation of laryngeal function in horses. Equine Vet J. 39, 553556

Martin B. B. Jr, Reef V. R., Parente E.J., Sage A. D. (2000) Causes of poor performance of horses during training, racing, or showing: 348 cases (1992-1996). J. Assoc. Med. Assoc. 216, 554-558

Morris E. A., Seeherman H. J. (1990) Evaluation of upper respiratory tract function during strenuous exercise in racehorses. J. Assoc. Med. Assoc. 196, 431-438

Ohnesorge B., Deegen E., Jöchle W. (1991) Zur Wirkung des Sedativums und Analgetikums Detomidin im Rahmen der Laryngoskopie von erwachsenen Pferden und Fohlen. Berl. Münch. Tierärztl. Wochenschr. 104, 340-346

Parente E. J., Martin B. B. Jr, Tulleners E. P., Ross M. W. (2002) Dorsal displacement of the soft palate in 92 horses during high-speed treadmill examination (1993-1998). Vet. Surg. 31, 507-512

Parente E. J., Martin B. B. Jr, Tulleners E. P., Ross M. W. (1994) Upper respiratory dysfunction in the horse during high-speed exercise. Proc. Am. Assoc. Equine. Pract. 40, 81-82

Parente E. J., Martin B. B. Jr. (1995) Correlation between standing endoscopic examination and those made during highspeed exercise in horses: 150 cases. Am. Ass. Equine. Pract. Proc. 41, 170171

Parente E. J. (2004) Treadmill endoscopy. Equine Vet. Ed. 16, 250 254

Rakestraw P. C., Hackett R. P., Ducharme N. G., Nielan G. J., Erb H. N. (1991) Arytenoid cartilage movement in resting and exercising horses. Vet. Surg. 20, 122-127

Ricketts S. W. (1986) Clinical experience with Domosedan in equine practice in Newmarket. Acta Vet. Scandinavica 82, 197-201

Strand E., Fiordbakk C. T., Holcombe S. J., Risberg A., Chalmers H. J. (2009) Effect of poll flexion and dynamic laryngeal collapse on tracheal pressure in Norwegian Coldblooded Trotter racehorses. Equine Vet. J. 41, 59-64

Tan R. H., Dowling B. A., Dart A. J. (2005) High-speed treadmill videoendoscopic examination of the upper respiratory tract in the horse: the results of 291 clinical cases. Vet. J. 170, 243-248 


\section{Entwicklung der Funktion von Larynx und Pharynx unter einer Langzeitbelastung auf dem Laufband beim Warm- blutpferd}

\begin{abstract}
Zusammenfassung
Ziel der Studie war es, den Einfluss einer Langzeitbelastung auf dem Hochgeschwindigkeitslaufband auf die Funktion der oberen Atemwege beim Warmblutpferd zu untersuchen. Zwei laufbandendoskopische Untersuchungen wurden an 16 Pferden nach einer Aufwärmphase und am Ende einer standardisierten Belastung von 25 Minuten durchgeführt. 9 der 16 Pferde zeigten ein Atemgeräusch und 6 fielen mit Anzeichen einer RLN (recurrent laryngeal neuropathy) von Grad Illa und höher bei der Endoskopie in Ruhe auf. 5 dieser 6 (83\%) entwickelten einen dynamischen Larynxkollaps auf dem Laufband. Keines der 7 Pferde ohne Atemgeräusch entwickelte einen dynamischen Larynxkollaps unter Belastung. Pathologische Befunde an den oberen Atemwegen zeigten eine Tendenz zur Verschlechterung unter längerer Belastung. Alle 5 Pferde mit dynamischem Larynxkollaps waren bereits in der Ruheendoskopie ohne Sedierung nicht in der Lage, vollständig zu abduzieren. 3 von ihnen $(60 \%)$ zeigten eine Verschlechterung während der Laufbandendoskopie $(p=0,017)$. Ein partieller Pharynxkollaps wurde bei 10 Pferden festgestellt, von denen aber nur $5(50 \%)$ gleichzeitig ein Atemgeräusch hatten. Insgesamt wurden nur bei 6 der 9 Pferde mit Atemgeräusch (67\%) Obstruktionen im Bereich des Larynx oder des Pharynx diagnostiziert. Die Ergebnisse zeigen, dass sich pathologische Befunde an den oberen Atemwegen des Pferdes über die Daver einer Belastung verschlechtern können. Daher sollten belastungsendoskopische Untersuchungen über das Auftreten des Atemgeräusches oder eines entsprechenden Befundes hinaus der Nutzung des Pferdes entsprechend fortgesetzt werden, um das volle Ausmaß der Erkrankung diagnostizieren zu können.
\end{abstract}

Schlüsselwörter: Pferd, Belastung, Endoskopie, Hochgeschwindigkeitslaufband, RLN

\section{Einleitung}

Die Diagnostik oberer Atemwegserkrankungen des Pferdes beruht routinemäßig auf der Belastungsuntersuchung an der Longe oder unter dem Reiter auf das Vorliegen eines Atemgeräusches in Kombination mit der ruheendoskopischen Untersuchung mit oder ohne Sedierung. Dynamisch-stenotische Erkrankungen der oberen Atemwege können jedoch nur selten ruheendoskopisch diagnostiziert werden. Die Belastungsendoskopie stellt daher für obere Atemwegserkrankungen des Pferdes den aktuellen Goldstandard dar (Franklin et al. 2008). Eine belastungsendoskopische Untersuchung kann auf einem Hochgeschwindigkeitsaufband oder mittels mobiler, sogenannter Overground-Systeme unter dem Reiter erfolgen, eine Technik, die in den letzten Jahren zunehmend zur Verfügung steht. Leider liegen bislang deutlich weniger Daten für als Sportpferde genutzte Warmblüter im Vergleich zu Trabund Galopprennpferden vor.
Die RLN (recurrent laryngeal neuropathy) ist nach internationaler Ansicht die einzige dynamisch-stenotische Erkrankung der oberen Atemwege, die auch ruheendoskopisch mit ausreichender Sicherheit in der Mehrzahl der Fälle diagnostizierbar ist. In zahlreichen Studien (Parente et al. 1995, Hammer et al. 1998, Martin et al. 2000, Tan et al. 2005, Lane et al. 2006b, Franklin et al. 2006) zeigten $82-100 \%$ der Pferde, die bei der Ruhendoskopie den linken Aryknorpel nicht vollständig abduzieren konnten, einen dynamischen Larynxkollaps unter Belastung, während andere Autoren (Rakestraw et al. 1991) in der Mehrheit der Fälle keinen dynamischen Kollaps beobachten konnten. Unterschiede in der Intensität und Daver der Belastung stellen eine mögliche Erklärung für diese Diskrepanz der Studienergebnisse dar (Hammer et al. 1998). Daher sollte in der vorliegenden Studie der Einfluss einer Langzeitbelastung auf die Entwicklung dynamischer Stenosen der oberen Atemwege an Warmblutpferden untersucht werden.

\section{Material und Methode}

16 Patienten und klinikeigene Pferde wurden an der Klink für Pferde der Stiftung Tierärztliche Hochschule Hannover untersucht. Es handelte sich um Warmblüter unterschiedlichen Alters (3- 18 Jahre), Gewichts (535-695kg), Größe (164-187cm) und Geschlechts (2 Stuten, 2 Hengste, 12 Wallache) mit einem vorberichtlichen Atemgeräusch und/oder Leistungsinsuffizienz. Ausschlusskriterien waren eine Größe von weniger als $150 \mathrm{~cm}$, ein Alter unter 2 bzw. über 20 Jahre, Erkrankungen des HerzKreislaufsystems, der tiefen Atemwege oder des Bewegungsapparates. Erkrankungen der oberen Atemwege, exklusive der RLN und der während der Ruheendoskopie spontan auftretenden, reponierbaren Dorsalverlagerung des Gaumensegels, führten ebenfalls zum Ausschluss von der Studie.

Die Pferde wurden standardisiert an der Longe belastet, 5 Minuten ausgebunden im Trab und je 5 Minuten ausgebunden und 2,5 Minuten ohne Ausbindung im Galopp auf beiden Händen. Die im Rahmen der Longenbelastung auftretenden Atemgeräusche wurden dokumentiert und anschließend eine Einteilung der Probanden in fünf Kategorien (Tabelle 1) vorgenommen. Pferde ohne Atemgeräusch dienten im weiteren Verlauf als Kontrollgruppe.

Für die endoskopische Untersuchung wurde ein flexibles Endoskop von 1,30m Länge und einem Durchmesser von 9,8 mm verwendet (Olympus Exera CLV-160, Olympus Corporation, Tokyo, Japan). Die Pferde wurden vor und nach Sedierung über den rechten ventralen Nasengang untersucht. Die Bewegungen des Larynx wurden in Ruhe, nach nasaler Okklusion über 30 Sekunden und nach Induktion des Schlukkaktes durch Berühren der Epiglottis mit einem Katheter im Arbeitskanal aufgezeichnet. Nach der Untersuchung im unsedierten Zustand, wurden die Pferde mit Detomidinhydrochlorid (Domosedan, Pfizer GmbH, Karlsruhe, Deutschland) in einer Dosierung von $12-15 \mathrm{~g} / \mathrm{kg}$ i.v. sediert und nach $3-5$ Minuten erneut endoskopiert.

Mit Hilfe des Videoverarbeitungsprogramms MPEG-Wizzard (Womble Multimedia Inc., USA) wurde je eine kurze 2-3 minütige Videosequenz im unsedierten und sedierten Zustand erstellt, die jeweils mindestens 1 Minute Ruheatmung, einen Schluckakt und eine Sequenz nasaler Okklusion enthielt. Diese anonymisierten Sequenzen wurden dann verblindet und 
von drei unabhängigen Beurteilern entsprechend des Scoring-Systems nach Dixon (2003, Tabelle 2) klassifiziert.

Die Belastungsendoskopie wurde auf dem Hochgeschwindigkeitslaufband "Kagra Mustang 2200" (Grabner AG, Fahrwangen, Schweiz) durchgeführt, nachdem die Pferde zwei- bis fünfmal, je nach Bedarf, auf dem Laufband antrainiert worden waren. Die Aufwärmphase bestand aus 5 Minuten Schritt bei $3 \%$ iger Steigung und einer Geschwindigkeit von $1,8 \mathrm{~m} / \mathrm{sec}, 2$ Minuten Arbeitstrab bei 3,6 m/sec und 1 Minute Mittelgalopp bei $7,6 \mathrm{~m} / \mathrm{sec}$. Danach wurde das Laufband kurz angehalten, um das Endoskop im rechten ventralen Nasengang zu fixieren. Die Pferde wurden über 3 Minuten bei $7,6 \mathrm{~m} / \mathrm{sec}$ laufbandendoskopisch untersucht, danach wurde das Endoskop wieder entfernt, und die Pferde nach einem standardisierten Protokoll weiter belastet (5 Minuten Trab bei 3,6 m/sec, 2 Minuten Galopp bei 7,6 m/sec, 5 Minuten Trab bei 3,6 $\mathrm{m} / \mathrm{sec}, 2$ Minuten Galopp bei 7,6 m/sec und 5 Minuten Trab bei 3,6 m/sec). Anschließend wurde das Endoskop erneut eingeführt und die Pferde erneut für 3 Minuten bei 7,6 m/sec im Galopp endoskopiert. So wurden laufbandendoskopische Sequenzen des Pharnyx und des Larynx am Anfang und am Ende der Belastung erstellt, zwischenzeitlich wurde das Endoskop entfernt, um Schäden an der Rachenschleimhaut zu vermeiden. Die Untersuchung auf dem Hochgeschwindigkeitslaufband erfolgte mit einem flexiblen Endoskop von 1,60 m Länge und einem Durchmesser von $9,8 \mathrm{~mm}$ (ETM Vidoetuning, Dr. Fritz GmbH, Tuttlingen, Deutschland). Die Videos wurden digitalisiert und bearbeitet mittels MPEG-Wizzard (Womble Multimedia Inc., USA) und anschließend von drei Untersuchern bei Originalgeschwindigkeit und in Zeitlupe bei $50 \%$ iger Originalgeschwindigkeit beurteilt. Pathologische Befunde im Sinne eines Pharynx- oder Larynxkollaps wurde vergleichend für die beiden zweiminütigen Sequenzen am Anfang und am Ende der Belastung beschrieben. Aufgrund der geringen Fallzahl wurde der Fischer-Yates-Test verwendet um, um die bedingte Wahrscheinlichkeit für eine Verschlechterung der pathologischen Befunde über die Langzeitbelastung zu testen.

\section{Ergebnisse}

a) Endoskopie in Ruhe

Die Ergebnisse der endoskopischen Untersuchung der Kehlkopfmotorik in Ruhe nach Dixon (2003, Tabelle 2) sind in Tabelle 3a (Pferde ohne Atemgeräusch) und in Tabelle 3b (Pferde mit Atemgeräusch) vergleichend zum festgestellten Atemgeräusch unter Longenbelastung und zum belastungsendoskopischen Befund auf dem Hochgeschwindigkeitslaufband dargestellt.

Alle Pferde ohne Atemgeräusch wurden der Kontrollgruppe zugeordnet und zeigten durchgehend Befunde für RLN von weniger als Grad III während der ruheendoskopischen Untersuchung vor Sedierung, ein Pferd wurde nach Sedierung als Grad IIIb eingestuft und ein Pferd blieb zweifelhaft in der Klassifizierung (Nr. 9, Tabelle 3a). 11 der 16 Pferde wurden nach Sedierung mindestens einen Grad höher bewertet, bei 5 Pferden änderte sich der Befund vor und nach Sedierung nicht (Tabelle 3a und 3b). Die 3 Pferde mit vollkommen symmetrischen und synchronen Larynxbewegungen vor Sedierung zeigten zeitweise oder daverhaft asymmetrische und/oder asynchrone Bewegungen der Stellknorpel nach Sedierung, behielten jedoch die Fähigkeit zur vollständigen Abduktion.

\section{b) Ergebnisse der Belastungsendoskopie}

Die Ergebnisse der Belastungsendoskopie der 7 Pferde ohne Atemgeräusch (Kontrollgruppe) sind in Tabelle 3a, die Ergebnisse der 9 Pferde mit Atemgeräusch sind in Tabelle 3b dargestellt. Bei 5 Pferden mit Atemgeräusch wurde unter Belastung ein partieller dynamischer Larynxkollaps festgestellt, wobei bei 4 Pferden der linke und bei einem Pferd der rechte Aryknorpel betroffen war. Obwohl dieser Befund bei allen 5 bereits am Anfang der Belastung sichtbar war, verschlechterte sich der Befund bei 3 Pferden (67\%) im Laufe der Belastung. Ein vollständiger Larynxkollaps trat bei keinem Pferd weder am Anfang noch am Ende der Belastung auf. Die Verschlechterung der maximalen Abduktion des linken Aryknorpels zum Ende der Belastung im Vergleich zum Anfang der Belastung ist in Abbildung $1 \mathrm{a}$ und $1 \mathrm{~b}$ bei Pferd Nr. 14 zu sehen. Alle 5 Pferde waren in der Ruheendoskopie nicht in der Lage, die vollständige Abduktion des betroffenen Stellknorpels zu erreichen und zu halten (Tabelle 3b). Keines der Pferde ohne Atemgeräusch (Kontrollgruppe, Tabelle 3a) zeigte Anzeichen eines Larynxkollaps unter Belastung.

Ein dynamischer Stimmfaltenkollaps war bei 3 Pferden unter Belastung erkennbar. Ein Pferd zeigte einen Kollaps beider Stimmfalten in Kombination mit einem linksseitigen Stellknorpelkollaps am Anfang und am Ende der Belastung, während die anderen beiden Pferde den Stimmfaltenkollaps erst im Laufe der Belastung entwickelten.

9 der 16 Pferde zeigten ein exspiratorisches Abduktionsdefizit (EAD, reduzierte Abduktion während der Exspiration) zu Beginn der Belastung. Bei 7 Pferden (78\%) verdeutlichte sich dieser Befund zum Ende der Laufbandendoskopie. Bei 7 Pferden blieben beide Stellknorpel vollständig abduziert während der In- und Exspiration für die gesamte Daver der Belastung. Bei 3 Pferden wurde eine axiale Deviation der Plica aryepiglottica (ADAF) während der Belastungsendoskopie festgestellt, welcher bei 2 Pferden bereits von Beginn an erkennbar war, bei einem Pferd hingegen erst unter längerer Belastung. Bei allen 3 Pferden war die rechte Plica aryepiglottica betroffen, obwohl 2 der 3 Pferde in der Ruheendoskopie eine linksseitige RLN gezeigt hatten. Eines der Pferde (Nr. 15) fiel zusätzlich zu der rechtsseitigen ADAF mit einem kombinierten Stellknorpel- und Stimmbandkollaps auf beiden Seiten auf (Tabelle 3b).

Ein partieller Kollaps des Rachendachs (PRC) wurde bei 9 Pferden diagnostiziert. Bei 5 Pferden senkte sich das Rachendach nur bis zur oberen Grenze der Stellknorpel, bei 4 Pferden lag ein stärkerer Kollaps vor. 2 Pferde (22\%) zeigten eine Verschlechterung unter Belastung, während ein vollständiger Kollaps bei keinem Pferd zu keinem Zeitpunkt der Belastungsendoskopie vorlag. Bei den restlichen 7 Pferden befand sich das Rachendach zu allen Zeitpunkten oberhalb der Aryknorpel.

2 Pferde zeigten einen geringgradigen partiellen Kollaps der seitlichen Rachenwände (PWC), wobei die Rachenwände zu keinem Zeitpunkt die Seitenränder der Epiglottis verdeckten. Die Befunde änderten sich zwischen Beginn und Ende der Belastung nicht. 
Mit Hilfe des Fisher-Yates-Tests wurde eine signifikante Verschlechterung der pathologischen Veränderungen für die RLN (Kollaps der Stellknorpel) zwischen Beginn und Ende der Belastung nachgewiesen $(p=0,017)$, während die Verschlechterung für andere Pathologien wie den Kollaps des Rachendachs (PRC) nicht signifikant war. Bislang existiert kein Scoring-System für das exspiratorische Abduktionsdefizit (EAD), daher konnte eine mögliche Signifikanz der Verschlechterung nicht errechnet werden.

\section{c) Atemgeräusche}

9 der untersuchten 16 Pferde fielen mit einem Atemgeräusch unter Longenbelastung (Tabelle 3b) auf, bei dem es sich um ein kontinuierliches oder diskontinuierliches hochfrequentes Atemgeräusch handelte, was als sogenanntes "Kehlkopfpfeifen" typisch für die RLN angesehen wird. Bei 2 (Nr. 2 und Nr. 14) dieser 9 Pferde wurde zusätzlich ein atypisches Geräusch festgestellt. Bei 5 (Nr. 4 und Nr. 13-16) dieser 9 (56\%) wurde tatsächlich ein partieller Stellknorpelkollaps laufbandendoskopisch diagnostiziert. Pferd Nr. 10 zeigte keinen Stellknorpel- oder Stimmfaltenkollaps unter Belastung, jedoch eine axiale Deviation der rechten Plica aryepiglottica, welche synchron mit dem Atemgeräusch auftrat. Bei 3 Pferden mit typischem "Kehlkopfpfeifen" (Nr. 2, 3 und 12) wurde lediglich eine leichte Einengung des Rachens durch das Rachendach oder die Seitenwände festgestellt, während sich der Larynx unauffällig zeigte. Bei einem (Nr. 1) von 7 Pferden ohne Atemgeräusch (Tabelle 3a) wurde eine ADAF festgestellt, bei einem weiten Pferd (Nr. 8) wurde der kaudale Anteil des weichen Gaumens unter Belastung zunehmend instabil, woraus sich ein DDSP (dorsal displacement of the soft palate) entwikkelte, und bei den restlichen 5 Pferden (Nr. 5-7, 9 und 11) war lediglich eine leichte Einengung des Rachens durch das Rachendach oder die Seitenwände sichtbar, während am Larynx keine Befunde zu erheben waren.

\section{Diskussion}

Das Ziel der vorliegenden Studie lag darin, den Effekt einer Langzeitbelastung auf dem Laufband auf die oberen Atemwege vergleichend zu den ruheendoskopischen Befunden vor und nach Sedierung bei Pferden mit und ohne Atemgeräusch zu untersuchen. Die Kehlkopfmotilität vor und nach Sedierung wurde wie in früheren Studien (Ricketts et al. 1986, Ohnesorge et al. 1991, Lindegaard et al. 2007, Barton et al. 2011) verblindet von drei unabhängigen Untersuchern bewertet. Die Fähigkeit zur vollständigen Abduktion des linken Aryknorpels bzw. das Abduktionsdefizit wurden nach dem Schluckakt bewertet, da dieses bei Pferden mit RLN zur bestmöglichen Abduktion führt (Barton et al. 2011 ). Im sedierten Zustand kam es bei der Mehrheit der Pferde in der Ruheendoskopie zu einer Verstärkung des Abduktionsdefizits. Auch Archer et al. (1991) beschrieben eine reduzierte Fähigkeit zur Abduktion des linken Stellknorpels nach der Applikation von Xylazin. Detomidin verursachte bei einigen Pferden asymmetrische Larynxbewegungen, die vor Sedierung nicht sichtbar waren (Lindegaard et al. 2007), was sich mit den Ergebnissen unserer Studie deckt. 3 von 16 Pferden zeigten erst nach Sedierung asymmetrische Stellknorpelbewegungen. In einer Studie von Ducharme et al. (1991) lag der Anteil der Pferde, die unter Sedierung die Fähigkeit zur vollständigen Abduktion nach Induktion des Schluckaktes verloren, bei 10\%. Dieses verstärkte Abduktionsdefizit unter Sedierung ist mit Sicherheit keine pharmakologische Nebenwirkung des Sedativums. Bereits in einer frühen Studie kam Cook (1981) zu dem Schluss, dass eine systemisch applizierte Substanz wie Detomidin, die auf die Synapsen im ZNS wirkt, keinen unilateralen Effekt auf den linken N. laryngeus recurrens und somit auf die intrinsische Larynxmuskulatur haben kann. Außerdem zeigten nur einige Pferde dieses meist linksseitige Abduktionsdefizit unabhängig von der verwendeten Dosierung des Sedativums, daher kann das einseitige Abduktionsdefizit dieser Pferde nicht als Nebenwirkung der pharmakologischen Substanz oder als Artefakt gewertet werden. Es deutet wahrscheinlich eher auf eine frühe oder geringe neurogene Muskelatrophie hin. Einige Autoren konnten in ihren Studien zeigen, dass die histopathologischen Veränderungen im Sinne einer Muskelatrophie meist weiter fortgeschritten sind als das endoskopische sichtbare Abduktionsdefizit vermuten lässt (Deegen et al. 2000, Duncan et al. 1974 und 1977). Zusammenfassend könnte die endoskopische Untersuchung unter Sedierung also helfen, subklinische Fälle von RLN zu identifizieren, welche mit asymmetrischen Kehlkopfbewegungen oder einem Abduktionsdefizit unter Sedierung auffallen. Um diese Befunde am sedierten Pferd besser interpretieren zu können, sollte eine größere Anzahl entsprechender Pferde unter Belastung endoskopiert werden. Keines der 3 Pferde in der vorliegenden Studie, die nach Sedierung mit asymmetrischen Larynxbewegungen auffielen, entwickelte einen dynamischen Larynxkollaps auf dem Laufband. Da diese Pferde unter Belastung zur vollständigen Abduktion ihrer Aryknorpel fähig waren, scheinen sie klinisch nicht an RLN erkrankt zu sein, obwohl histologische Veränderungen einer neurogenen Muskelatrophie bereits vorliegen und diese in der Zukunft zur laryngealen Dysfunktion unter Belastung führen könnten.

6 Pferde, 2 vor Sedierung und 4 nach Sedierung, konnten ruheendoskopisch nicht nach Dixon (2003) klassifiziert werden, da ihre Befunde im Laufe der Untersuchung variierten (Tabelle 3a und 3b). Dies ist insbesondere bei der Differenzierung zwischen Grad Ilb und IIla bedeutsam, da diese Grenze als klinisch relevant für die Diagnose einer RLN gilt. Selbst Fälle, bei denen eine klare Klassifizierung anhand ihrer Abduktionsfähigkeit nach Induktion des Schluckaktes getroffen werden konnte, können problematisch werden, da mehrere Studien (Morris et al. 1990, Rakestraw et al. 1991, Parente 1995, Hammer et al. 1998, Martin et al. 2000, Tan et al. 2005, Lane et al. 2006) gezeigt haben, dass sogar Pferde, die nach nasaler Okklusion oder Induktion des Schlukkaktes nicht vollständig abduzieren konnten, in einigen Fällen eine physiologische Larnyxfunktion auf dem Hochgeschwindkeitslaufband zeigen können. Auf der anderen Seite kann es bei einer geringen Anzahl Pferde, die ruheendoskopisch keine Hinweise auf eine Dysfunktion des Kehlkopfes zeigen, während der Belastungsendoskopie zu einem dynamischen Larynxkollaps kommen. Für die Diagnose einer klinischen RLN Erkrankung sollte daher bei ruheendoskopisch unklaren Fällen wenn möglich eine belastungsendoskopische Untersuchung in Betracht gezogen werden. Dies gilt insbesondere für Beurteilungen beim Pferdekauf und Körentscheidungen.

Die belastungsendoskopische Untersuchung auf dem Hochgeschwindigkeitslaufband erfolgte zu Beginn und am Ende einer standardisierten Belastung, die in Anlehnung an die typische Arbeit eines Sportpferdes aus alternierenden Phasen von Trab und Galopp bestand. Die Geschwindigkeit des Lauf- 
bandes im Trab betrug 3,6 m/sec, was dem Arbeitstrab entspricht. Im Galopp wurde eine dem Mittelgalopp entsprechende Geschwindigkeit von 7,6 m/sec gewählt, was über der Geschwindigkeit des Arbeitsgalopps von $5-5,5 \mathrm{~m} / \mathrm{sec}$ liegt, um das fehlende Reitergewicht und die fehlende Beizäumung des Dressurpferdes zu kompensieren. Im Springreiten und in der Vielseitigkeit sind ebenfalls Galoppgeschwindigkeiten oberhalb des Arbeitstempos gefordert. Es erschien wenig sinnvoll, für das Warmblutpferd ein in der Literatur beschriebenes Belastungsprotokoll zu verwenden oder die verwendete Belastung mit diesen Protokollen zu vergleichen (Morris and Seehermann 1990, Rakestraw et al. 1991, Parente 1995, Hammer et al. 1998, Martin et al. 2000, Tan et al. 2005, Lane et al. 2006), da alle diese Studien an Trabern und Galopprennpferden durchgeführt wurden. Nach unserem Wissenstand handelt es sich bei der vorliegenden Studie um die erste Untersuchung auf dem Hochgeschwindigkeitslaufband an Warmblutpferden, die als Sportpferde unter ganz anderen Umständen arbeiten und oft in einem höheren Alter sportlich genutzt werden als Vollblüter.

Ein dynamischer Larynxkollaps kann als alleiniger Kollaps der Aryknorpel, der Stimmfalten oder als Kombination aus beiden auftreten (Tan et al. 2005, Lane et al. 2006a). Der linksseitige Stellknorpelkollaps wird mit hoher Wahrscheinlichkeit durch eine RLN verursacht (Lane et al. 2006). In verschiedenen Studien konnte gezeigt werden, dass $82-100 \%$ der unsedierten Pferde, die ruheendoskopisch die vollständige Abduktion des linken Aryknorpels nicht erreichen und halten können, einen dynamischen Larynxkollaps unter Belastung entwickeln (Parente 1995, Hammer et al. 1998, Martin et al. 2000, Tan et al. 2005, Lane et al. 2006b, Franklin et al. 2006). Auf der anderen Seite entwickeln nur 0-26\% der Pferde ohne Abduktionsdefizit in der Ruheendoskopie einen dynamischen Kollaps auf dem Hochgeschwindigkeitslaufband. In der vorliegenden Studie zeigten 4 Pferde (Nr. 4 und Nr. 14-16) ein permanentes Abduktionsdefizit vor Sedierung in der Ruheendoskopie (Grad IIla/IIlb) und ein Pferd (Nr. 13) konnte nur nach Sedierung nicht mehr vollständig abduzieren. Keines der Pferde, welche die vollständige Abduktion in der Ruheendoskopie vor Sedierung erreichen und halten konnten, entwickelte einen dynamischen Larynxkollaps unter Belastung. Unsere Ergebnisse decken sich somit mit den Beschreibungen am Vollblutpferd. Nichtsdestotrotz bleibt zu bedenken, dass bis zu 18\% der Pferde mit einem Abduktionsdefizit in der Ruheendoskopie unter Belastung die vollständige Abduktion erreichen und dass bis zu $26 \%$ der ruheendoskopisch unauffälligen Pferde unter Belastung einen dynamischen Larnyxkollaps entwickeln. Eine belastungsendoskopische Untersuchung sollte daher in jedem Fall empfohlen werden, bei der eine definitive Klassifizierung der tatsächlichen, klinischen Erkrankung einer RLN erforderlich ist.

Bei 3 (Nr. 14-16) der 5 Pferde, die einen dynamischen Larnyxkollaps in dieser Studie auf dem Laufband entwickelten, zeigte sich eine Verstärkung des Abduktionsdefizits zwischen der ersten und der zweiten Belastungsendoskopie. Eine fortgeschrittene neurogene Muskelatrophie der intrinsischen Kehlkopfmuskeln führte hier möglicherweise zu einer Ermüdung der Muskulatur und somit zur reduzierten Fähigkeit, die Aryknorpel über die Daver der Belastung zu abduzieren. Eine andere Erklärung besteht in einer Erhöhung des Unterdrucks in der Inspiration unter intensiver Atmung, wodurch der linke Aryknorpel vermehrt in das Kehlkopflumen gezogen wird. Die gebräuchliche Definition der klinischen Erkrankung des Kehlkopfpfeifens als Kombination aus einem typischen inspiratorischen Atemgeräusch unter Belastung und einem Abduktionsdefizit vom Grad Illa oder mehr wird durch die Ergebnisse unserer Studie bestätigt, da alle Pferde mit einem dynamischen Stellknorpelkollaps diese Kriterien erfüllten. Bei 2 der 3 Pferde, die unter längerer Belastung eine Verschlechterung ihres Stellknorpelkollaps (ACC) zeigten, lag bei der zweiten Endoskopie ein ipsilateraler Stimmfaltenkollaps (VCC) vor. Dies unterstützt die generelle Annahme, dass ein Stimmfaltenkollaps üblicherweise sekundär zu einem Stellknorpelkollaps auftritt (Parente 2004). Bei einem Pferd entwickelte sich jedoch ein rechtsseitiger Stimmfaltenkollaps ohne entsprechenden Stellknorpelkollaps. Ein isolierter Stimmfaltenkollaps wurde von verschiedenen Autoren beschrieben (Morris und Sehermann 1990, Rakestraw et al. 1991, Kannegieter und Dore 1995, Kings et al. 2001, Franklin et al. 2006, Lane et al. 2006b). Die Ätiologie ist bislang unbekannt, eine subtile Form von RLN wird vermutet (Kings et al. 2001).

Keines der Pferde mit vollständiger Aryknorpelabduktion bei der ersten Endoskopie entwickelte ein Abduktionsdefizit bis zur zweiten Untersuchung am Ende der Belastung. Bei den Pferden Nr. 10 - 13 war der Ausgang der Belastungsendoskopie ruheendoskopisch nicht vorhersagbar. Die Sedierung könnte zu einer besseren Erkennung eines Abduktionsdefizits führen, welches dann auf dem Laufband klinisch relevant wird (Pferd Nr. 13), oder ein Abduktionsdefizit unter Sedierung könnte auch keinen prädiktiven Wert haben (Pferd 9, 10 und 12). Das Atemgeräusch der Pferde Nr. 10 und 12 wurde wahrscheinlich eher durch die ADAF oder den partiellen Rachenkollaps verursacht, obwohl ruheendoskopisch Hinweise auf RLN vorlagen. Auf dem Laufband zeigten beide Pferde jedoch eine vollständige und daverhafte Abduktion der Aryknorpel.

9 der insgesamt 16 Pferde zeigten während der Exspiration keine vollständige Abduktion der Aryknorpel zu Beginn der Belastung, bei 7 verschlechterte sich dieser Befund zum Ende hin. Im Gegensatz zum inspiratorischen Abduktionsdefizit, wurde ein exspiratorisches Abduktion bislang nicht in der Literatur beschrieben. Da sich keine Korrelation zu den ruhe- und belastungsendoskopischen Befunden einer RLN ergab, bleibt die pathologische Relevanz zu diesem Zeitpunkt ungeklärt. Da sich der Befund bei den meisten Pferden über die Daver der Belastung verstärkte, kann hier ebenfalls eine Ermüdung der Abduktoren ätiologisch vermutet werden. Obwohl dies auf eine Muskelschwäche hinweisen könnte, erscheint der Befund irrelevant hinsichtlich seiner klinischen Bedeutung, da ein exspiratorisches Abduktionsdefizit die physiologische Atmung nicht beeinträchtigt.

Die axiale Deviation der Plica aryepiglottica (ADAF), die oft aufgrund eines vorberichtlichen Atemgeräuschs oder einer Leistungsschwäche diagnostiziert wird, wird mit einer Prävalenz von 5-55\% beim Rennpferd beschrieben (Morris und Sehermann 1990, Rakestraw et al. 1991, Kannegieter und Dore 1995, Kings et al. 2001, Martin et al. 2000). Die ADAF kann linksoder rechtsseitig sowie beidseitig auftreten und stellt oft den alleinigen belastungsendoskopischen Befund dar (Morris und Sehermann 1990, Rakestraw et al. 1991, Parente 1994, Kings et al. 2001, Martin et al. 2000), kann aber auch in Kombination mit anderen dynamisch-stenotischen oberen Atemwegser- 
krankungen auftreten (Morris und Sehermann 1990, Rakestraw et al. 1991). In der vorliegenden Studie wurde eine rechtsseitige ADAF bei 3 von 16 Pferden festgestellt, welche zum Ende der Belastung eine Tendenz zur Verschlechterung zeigte. Die Ätiologie ist ungeklärt, ein vermehrter inspiratorischer Unterdruck unter forcierter Atmung zum Ende der Belastung wird als wesentlicher Faktor angenommen. Parente (1994) vermutete einen Zusammenhang zu einer Dysfunktion des Gaumensegels. In unserer Studie ergab sich kein Zusammenhang zu anderen pathologischen Befunden der oberen Atemwege.

Eine Instabilität des kaudalen Anteils des weichen Gaumens mit charakteristischen, progressiven wellenartigen Bewegungen der Schleimhaut wurde von mehreren Autoren beschrieben (Morris und Sehermann 1990, Rakestraw et al. 1991, Kings et al. 2001) und geht oft einer Dorsalverlagerung des weichen Gaumens (DDSP) voraus. Diese beiden Befunde wurden daher als zwei Ausprägungen derselben Erkrankung beschrieben (Morris und Sehermann 1990), was bei dem einen betroffenen Pferd unserer Studie ebenfalls so schien. Das DDSP wurde nach wenigen Atemzügen spontan korrigiert, kurz danach traten jedoch erneute Wellenbewegungen des weichen Gaumens auf, was zu wiederkehrenden Dorsalverlagerungen des weichen Gaumens führte. Zum Ende der Belastung verschwand das DDSP jedoch. Es wurde vermutet, dass eine Instabilität des weichen Gaumens mit folgendem DDSP durch eine Retraktion des Kehlkopfes bei nervösen Pferden auftritt (Cook 1981), so dass eine längere Belastung und eine Ermüdung der den Kehlkopf zurückziehenden Muskulatur zu einer Stabilisierung des weichen Gaumens führen.

Der Pharynxkollaps ist eine seltene dynamisch-stenotische Erkrankung der oberen Atemwege beim Rennpferd, der nur bei 1,3-4 \% der Pferde, die aufgrund einer Leistungsinsuffizienz oder eines Atemgeräusches laufbandendoskopisch untersucht wurden, diagnostiziert wurde (Morris und Sehermann 1990, Rakestraw et al. 1991, Kings et al. 2001). Martin et al. (2000) hingegen beschrieben eine Prävalenz von $27 \%$, was möglicherweise durch den hohen Anteil von Trabern in dieser Studie zu erklären ist. Traber arbeiten unter stärkerer Anbeugung des Kopfes, was die Entwicklung eines Rachenkollaps begünstigt. Mehrere Autoren (Franklin et al. 2006, Cehak et al. 2010, Davidson et al. 2002, Strand et al. 2009) beschrieben eine erhöhte Prävalenz dieser Erkrankung bei Sport- im Vergleich zu Rennpferden. Strand et al. (2009) fand eine Korrelation zwischen Kopfposition und Pharynxkollaps beim Norwegischen Traber. In unserer Studie wurde bei 8 Pferden ein Kollaps des Rachendachs, bei einem Pferd der Seitenwände und bei einem Pferd eine Kombination aus Kollaps von Rachendach und Seitenwänden festgestellt (Tabelle $3 a$ und $3 b)$. Nur in zwei Fällen verschlechterte sich der Befund zum Ende der Belastung. Alle Befunde wurden nach Boyle et al. (2006) als geringgradig eingestuft. Die Ätiologie des dynamischen Pharnyxkollaps ist unbekannt. Auch bei dieser Erkrankung wird ein erhöhter inspiratorischer Unterdruck unter starker Belastung als wichtiger Faktor in der Entstehung vermutet.

Atemgeräusche können bei allen dynamisch-stenotischen Erkrankungen der oberen Atemwege des Pferdes entstehen. In dieser Studie konnte bei einem der 7 Pferde ohne Atemgeräusch eine moderate ADAF diagnostiziert werden. Kings et al. (2001) konnten nur bei $83 \%$ der Pferde mit einer ADAF ein zeitgleich zur Vibration der Schleimhaut auftretendes Atemgeräusch feststellen, $11 \%$ zeigten hingegen eine ADAF ohne entsprechendes Atemgeräusch. Eine ADAF mag somit nicht bei jedem Atemgeräusch als Erklärung ausreichen. Das gleiche gilt für den Pharynxkollaps, der in unserer Studie bei 5 von 7 Pferden ohne Atemgeräusch in geringer Ausprägung auftrat und auch bei Boyle et al. (2006) nur in 73 \% der Fälle mit einem Atemgeräusch einherging. Die Ergebnisse unserer Studie erlauben somit die Annahme, dass ein geringgradiger Pharynxkollaps in den meisten Fällen nicht zu einem Atemgeräusch führt. Weitere Studien unterstützen diese These, so berichten Franklin et al. (2006) lediglich von leisen inspiratorischen Atemgeräuschen bei einer Instabilität des Rachens und ein DDSP geht lediglich in bis zu 30\% der Fälle mit einem wahrnehmbaren Atemgeräusch einher (Martin et al. 2000, Parente 2002). Der Stellknorpelkollaps unter Belastung wurde hingegen in allen 5 Fällen unserer Studie durch ein hochfrequentes Atemgeräusch begleitet. Verschiedene Autoren (Moris und Sehermann 1990, Franklin et al. 2006) bestätigen dieses inspiratorische Atemgeräusch bei allen Pferden mit dynamischem Larynxkollaps in ihren Studien, auch wenn das Geräusch nicht zwangsläufig hochfrequent war. 3 Pferde in unserer Studie zeigten zwar ein Atemgeräusch, jedoch keine pathologischen Befunde in der Ruheendoskopie und auf dem Laufband außer einem geringgradigen Rachenkollaps und einem geringgradigen exspiratorischen Abduktionsdefizit, welche wahrscheinlich nicht die Ursache des Atemgeräusches waren. Atemgeräusche können auch durch turbulente Luftströme in den Nasengängen entstehen, diese Ursachen sind jedoch belastungsendoskopisch nicht zu erfassen.

Abschließend können sich pathologische Befunde an den oberen Atemwegen über die Daver einer Landzeitbelastung auf dem Hochgeschwindigkeitslaufband verändern, dieser Effekt konnte jedoch nur für den dynamischen Stellknorpelkollaps als signifikant nachgewiesen werden. Pathologische Befunde der Plica aryepiglottica, des weichen Gaumens und des Rachens verschlechterten sich in mehreren Fällen im Laufe der Belastung. Der Effekt könnte möglicherweise an größeren Fallzahlen signifikant sein. Die Frage, ob der dynamische Stellknorpelkollaps durch einen erhöhten inspiratorischen Unterdruck unter forcierter Belastung oder durch Ermüdung der intrinsischen abduzierenden Kehlkopfmuskulatur verursacht wird, bedarf ebenfalls größerer Fallzahlen und histopathologischer Untersuchungen. Da das Belastungsprotokoll jedoch für alle Pferde identisch war, erscheint die Ermüdung des atrophierten M. cricoarytenoideus dorsalis als wahrscheinlichere Erklärung.

In jedem Fall stellt die belastungsendoskopische Untersuchung auf dem Laufband oder mithilfe eines mobilen Endoskopiesystems eine wertvolle Technik für die Untersuchung oberer Atemwegserkrankungen dar. Daver und Intensität der Belastung sollten der Nutzung des Pferdes angepasst werden, um vermutete dynamisch-stenotische Erkrankungen reproduzieren zu können. Nur wenn das Atemgeräusch synchron mit einer sichtbaren Stenose der oberen Atemwege auftritt, kann die Diagnose als vollständig gesichert gelten. Belastungsendoskopische Untersuchungen sollten über das erste Auftreten des Atemgeräusches oder des pathologischen Befunden hinaus fortgesetzt werden, um das volle Ausmaß der Erkrankung erfassen zu können. 